\title{
A Literature Review of the Research on Modern Apprentice Management Mechanism*
}

\author{
Shijun Yuan \\ Hunan Modern Logistics College \\ Changsha, China 410131
}

\author{
Yuanqing $\mathrm{Hu}$ \\ Hunan Modern Logistics College \\ Changsha, China 410131
}

\begin{abstract}
Based on the analysis of the background of modern apprenticeship education, this paper reviews the research status at home and abroad on the basis of the definition of research topics, in order to comprehensively grasp the current research trends.
\end{abstract}

\section{Keywords—apprentice; management mechanism; research}

\section{INTRODUCTION}

In 2014, in the "Decision of the State Council on Accelerating the Development of Modern Vocational Education", the Special Requirements have been made for "the Implementation of the Joint Enrollment of Schools and Enterprises, the Joint Cultivation of Modern Apprenticeship System, the Improvement of Support Policies, and the Promotion of School-enterprise Integration Education". Modern apprenticeship has become an important strategy for the development of human resources in the country. In August 2014, the Ministry of Education issued the "Opinions on the Pilot of Modern Apprenticeship System”. In 2015 and 2017, the Ministry of Education selected 165 and 203 units to carry out the pilot program of modern apprenticeship. The establishment of modern apprenticeship is the active choice of vocational education to serve the current economic and social development requirements, promote the interactive development of the vocational education system and the labor employment system, open up and broaden the channels for training and growth of technical and technical personnel, and promote the strategic choice of the construction of modern vocational education system; It is an effective way to promote integration of schools and enterprises and promote the integration of engineering and learning.

At present, the school and enterprise jointly carry out the modern apprenticeship pilot in the form of "title (order) class" and "credit college". Among them, the "Double subjects" of the school and enterprise to jointly build the second-level college based on the "double identity" cultivation of modern apprentice is the most closely cultivated mode of talent training between schools and enterprises. In this training mode, modern apprentices are both "school students" and "corporate apprentices" and are trained and managed by "schools" and "enterprises." Establishing an effective "modern apprentice"

*Hunan Education Science Planning Project-Study on the "Double subjects and Dual Identity" Apprentice Collaborative Management Mechanism (XJK18BZY042) based on the school-enterprise joint construction of the second-level college. management mechanism is the key to the smooth development of this talent training model. It is also the key to realize the orderly operation of the "double-subject" second-level college talent training in schools and enterprises, and to ensure the quality of the "double-identity" modern apprentice talent training.

\section{THE DEFINITION OF THE SUBJECT}

School-enterprise cooperation: It is a cooperation model established between schools and enterprises. In 2018, the Ministry of Education and other six departments issued a "Procedures for Promoting School-Enterprise Cooperation in Vocational Schools" clearly stating that "integration of production and education, school-enterprise cooperation is the basic mode of running a vocational education, and is the key to running a vocational education well."

Modern Apprenticeship: It is a model proposed by the Ministry of Education of the People's Republic of China in 2014 to deepen the integration of production and education, school-enterprise cooperation, further improve the schoolenterprise cooperation and education mechanism, and innovate technical skills.

\section{Double subjects: school, enterprise}

Dual identity: school students, corporate employees

School-enterprise "double subjects" to build a modern apprenticeship second-level college is an important measure for the deep cooperation between schools and enterprises to deepen the integration of production and education. The apprentices have the dual identity of "corporate employees and school students", and the establishment of apprentice management mechanism is one of the key elements for the successful development of the apprenticeship second-level colleges. This study uses the theory of vocational education, the combination of engineering and other vocational education theory, the theory of demand hierarchy, and the theory of emotional management to build a school-enterprise double subjects and full life span the "dual identity" apprentice collaborative management mechanism to promote the development of the modern apprenticeship training model.

\section{REVIEW OF RESEARCH STATUS AT HOME AND ABROAD}

In China National Knowledge Infrastructure and other related databases, there is no relevant reference with the 
"apprenticeship management mechanism" as the key word. In this paper, the author takes the closest word "student management mechanism" to review the status quo of domestic and foreign research.

\section{A. Research on the Management Mechanism of Foreign Students}

At present, there are two typical student management models. One is in the United States and the United Kingdom, the other is in Japan and Germany.

1) Student management model in the US and the UK: The mechanism of school service. The UK is a multi-line horizontal mechanism for student affairs management. It is based on the school-college student affairs management system and mechanism. A student affairs agency is set up at the school level to face the work of all students. At the college level, the dean or department head is responsible for student affairs, and arranges a tutor for each student, and the tutors are responsible for all-round guidance of students. The college also assigns special personnel to carry out specific work such as career development and psychological counseling for students. They keep in touch with student affairs agency, but the school and the college are only cooperative and have no affiliation relationship.

2) Student management model in Germany and Japan: The mechanism of social services. In this model, it is advocated that the management of student affairs in colleges and universities should be undertaken by specialized social institutions rather than universities, and the school is mainly for communication and coordination. The relationship between students and schools in German university student affairs management is mainly based on civil relations, supplemented by administrative relations, emphasizing social services.

\section{B. Research on Student Management Mechanism}

At present, the research on student management mechanism mainly focuses on student management incentive mechanism, competition mechanism and self-management mechanism.

1) Incentive mechanism is a connecting means for students to transform their lofty ideals into concrete facts in student management: The application of incentive mechanism in student management in higher vocational colleges can help students establish a correct view of learning, build and consolidate self-confidence, and show their own value (Li Nan, 2009). At the same time, college student management incentive mechanism is also a systematic project, it not only must have scientific incentives, have a sound evaluation basis and standards, but also take the actual situation of students as reference, focus on the future development of students (Zhu Xiaoyang, 2013), help students set reasonable goals, and motivate students with specific and step-by-step goals (Chang Rui, 2016). In accordance with the five incentive principles, the combination of material incentives and spiritual incentives, directionality, systematicness, pertinence, and effectiveness (Ma Wujin, 1993) in the management of college students, it is necessary to adopt corresponding incentives according to different people from achievements and education and training these three aspects (Liu Zhiming, 2001), such as behaviororiented incentives, emotional incentives, negative incentives, reward incentives and self-motivation (Huang Xiaoyun, 2006). It is also possible to use the combination of the purpose education and the target incentives, role models, and emotional incentives (Song Guanghai, 2012).

2) The competition mechanism is the means and method for the survival of the fittest in student management: In student management, the competition mechanism is a better means and method to achieve students' survival of the fittest. The introduction of competition mechanism in student management must clarify its competition objectives, competition methods, and strengthen competition mechanisms (Zhang Xigong, 2000). The establishment of a competitive mechanism should be based on an objective scientific evaluation of students, and establish a management system that encourages the advanced, spurs the backward, and eliminates the unqualified people (Chen Xiulan, 1994), the competition mechanism should be introduced to study, life, political ideas, ethical behavior and graduation distribution and effectively regulate and control the mechanism. In terms of specific measures, give full play to the role of class and student cadres in student management (Wang Jinghai, Bi Zichuan, 1994), through the selection of "advanced classes", "civilization classes", "awards" and "appraising" activities to cultivate students' sense of competition (Wang Kezhen, 1991). It is possible to implement a comprehensive assessment, a step-by-step elimination system, a credit system and a grade point system, and a trial-and-recruit system for relegation fees and withdrawals (Guo Binwen, 1995).

3) Guiding students to self-manage for self-life value is the ultimate goal of student management: The self-management mechanism should follow five principles, namely, the principle of ideology, independence, organization, extension and phase (Bai Jun, 2000). Student self-management can be implemented from determining student management groups, student management project classification, and developing appropriate goals, establishing feedback correction network, and appropriating time (Sun Liangmeng, 1994); it can be divided into four levels: life, extracurricular cultural activities, business learning and ideological and moral behavior (Xuan Yong, Wang Xingjie, 1995), From the work concept, it can focus on the stimulation and guidance on the main body, establishing and improving various systems to form and improve the basic strategies of college students' self-management mechanism (Mao Cheng, Ye Zhengping, 2007), conducting admission management training from the beginning of the new student enrollment to develop students' self-management skills (Wang Quan, 2014). For higher vocational colleges, in the management of students, they must not only learn from the management methods of ordinary colleges, but also provide them with a lot of practical opportunities according to the characteristics of higher vocational students, so that students can lay a foundation for self-management in their selfrealization. Helping students learn goal management is the core of self-management, helping students learn time management is the guarantee of self-management, and it needs to careful situation design to promote students' selfmanagement with the project, and strive to form a systematic 
student management mechanism to promote student selfmanagement (Pang Libin, 2012).

\section{Research on Student Management Mechanism of School- enterprise Cooperation Talents Training}

In the training of school-enterprise cooperation talents, because the places involved in student management include enterprises and schools, classrooms and corporate sites, the management environment is more complicated. Therefore, it is necessary to adopt the concept of full school-enterprise cooperation student education management (Chen Biao, 2010). Taking nuanced ideological education, strengthening institutional constraints, weekly student information feedback, developing student safety plans, school and enterprise participation in student management, and regular visits by business leaders to strengthen student management (Liu Zengchao, Gao Shijie, 2007). Sanmenxia Vocational and Technical College and Henan Huanfa Engineering Co., Ltd. implemented a "mentor system" for joint training of students, and promoted the development of school-enterprise cooperation to a higher level (Sun Chaoyang, Yang Lan, 2010).

\section{Research on Talent Training and Life Cycle Theory}

The concept of the product life cycle was first proposed by Dean and Levirt to study the market strategy of the product. According to the evolution process of products in the market, the product life cycle should be divided into four stages: promotion, growth, maturity and decline. For more than 50 years, its concept and connotation have been continuously enriched and developed.

After the parallel project was put forward, the concept expanded from economic management to engineering. The scope of the product life cycle also expanded from the market to the development stage. The concept of the whole product life cycle was born: from product demand analysis and conceptual design, detailed design, manufacturing, packaging, transportation, sales, use, after-sales service, until the product recycling process. $\mathrm{Xu}$ Chonghai, Qin Menghua, and $\mathrm{Li}$ Hongxia (2012) proposed a full-life undergraduate talent training model based on "enrollment-cultivation-graduationemployment and social needs-social evaluation-lifelong learning".

\section{E. Preliminary Summary}

In summary, the research results of experts and scholars provide theoretical basis and practical experience for the establishment of incentive mechanism, competition mechanism and self-management mechanism, but research on the management mechanism of apprenticeship (student) of "dual identity" from the perspective of "double subjects" is rare. Especially in the existing research literature, there is no research on the modern apprenticeship management mechanism of the modern apprenticeship pilot, and no research on school-enterprise "double subjects" coconstruction of the second-level colleges of the modern apprenticeship management mechanism, no research on of the "dual identity" apprenticeship management mechanism based on the full life cycle theory, and no research on multi- dimensional collaborative management mechanism based on the above several fields.

\section{THE SIGNIFICANCE OF RESEARCH}

The research of this subject will theoretically fill the gap in modern apprenticeship pilot institutions and majors in modern apprenticeship management mechanism. In practice, it will provide theory basis for modern apprenticeship institutions (secondary institutes) and professional modern apprenticeship management. It also provides suggestions for the education department of our country to further develop the management regulations of "modern apprentices with double subjects and dual identities.

\section{CONCLUSION}

The research of this subject introduces the whole life cycle theory into the modern apprenticeship management, tries to divide the cultivation of modern apprentice into several stages, and forms a complete life cycle theory of modern apprenticeship training. At the same time, the results of this research will directly serve the apprenticeship management of the modern apprenticeship second-level colleges. Meanwhile, its experience can be popularized, and it can provide experience for more than 300 modern apprenticeship pilot institutions and enterprises.

\section{REFERENCES}

[1] Xu Chonghai, Qin Menghua, Li Hongxia. Reform of undergraduate talent training mode based on the perspective of full life cycle theory. China Light Industry Education. 2012.03. p3-6. (in Chinese)

[2] Wei Xiaoxu. A new exploration of the management mechanism of posttraining students in higher vocational colleges. Shandong Normal University. 2014. (in Chinese)

[3] Ji Yuedong. Construction of open student management mechanism under the combination of engineering and talent cultivation. Heilongjiang Higher Education Research. 2012 (in Chinese) 